\title{
Chlamydia trachomatis, human papillomavirus, bacterial vaginosis and cervical neoplasia
}

\author{
Eddie Fernando Candido Murta
}

Received: 15 January 2014 / Accepted: 24 January 2014 / Published online: 12 February 2014

(C) Springer-Verlag Berlin Heidelberg 2014

\section{Dear Editor,}

Chlamydia trachomatis (CT) and human papillomaviruses (HPV) may contribute to the development of cervical intraepithelial neoplasia (CIN) [1]. The association between HPV and bacterial vaginosis (BV) was described in pregnant women [2] or non-pregnant women [3]. One explication is host immune response variation [1]. Vaginal $\mathrm{pH}>4.5$ is another possibility found in cases of association between BV and HPV [2].

The review of Silva et al. [1] recently published in Arch Gynecol Obstet show studies about possible association between CT and HPV. The review is well conducted; nonetheless, two points could be addressed. First, the possible association among HPV, CT and BV must be discussed. In a meta-analysis [3], 12 eligible studies were selected to review the association between BV and HPV (total of 6,372 women). The overall estimated odds ratio (OR) showed a positive association between BV and cervical HPV infection (OR 1.43; $95 \%$ confidence interval 1.11-1.84). Other study [2] in pregnant women on association among HPV, CT and BV showed that compared to the group of pregnant women without HPV infection, those with HPV infection had a higher prevalence of BV (53.8 vs. $15.4 \% ; p=0.007$ ), and CT (34.6 vs. $7.7 \%$; $p=0.039$ ). All cases of CT and BV had high-grade HPV infection.
The other point is about some references. Figure 2a showed a graphic representation of approximated CT DNA prevalence (\%) in HPV-positive women, cervical neoplasia and/or invasive cervical cancer observed in some countries around the world. Look at references 62 and 70, both were cited as Brazilian studies but the analysis was conducted on Indians; another reference (69) described Colombian and not Brazilian patients. Although the merit of the paper is its expressiveness, I think these wrong citations must be corrected.

Conflict of interest I declare no conflict of interest in the letter to editor "Chlamydia trachomatis, human papillomavirus, bacterial vaginosis and cervical neoplasia" Eddie Murta.

\section{References}

1. Silva J, Cerqueira F, Medeiros R (2013) Chlamydia trachomatis infection: implications for HPV status and cervical cancer. Arch Gynecol Obstet. doi:10.1007/s00404-013-3122-3

2. da Silva CS, Adad SJ, Hazarabedian de Souza MA, Macedo Barcelos AC, Sarreta Terra AP, Murta EF (2004) Increased frequency of bacterial vaginosis and Chlamydia trachomatis in pregnant women with human papillomavirus infection. Gynecol Obstet Invest 58(4):189-193. doi:10.1159/000079822

3. Gillet E, Meys JF, Verstraelen H, Bosire C, De Sutter P, Temmerman M, Broeck DV (2011) Bacterial vaginosis is associated with uterine cervical human papillomavirus infection: a meta-analysis. BMC Infect Dis 11(11):10. doi:10.1186/1471-2334-11-10
E. F. C. Murta ( $\square)$

Research Institute of Oncology/Discipline of Gynecology and Obstetrics, Federal University of Triângulo Mineiro, Av. Getúlio Guarita, s/n, Bairro Abadia, Uberaba, MG 38025-440, Brazil

e-mail: eddiemurta@mednet.com.br 